\title{
Analysis Of The Effectiveness And Impact Of Less Human Resources In Improving Employee Performance At Pt Bank Sumut Syariah Kcp Kisaran
}

\author{
Dinda Aprilia ${ }^{1}$, Annio Indah Lestari Nasution ${ }^{2}$ \\ Universitas Islam Negeri Sumatera Utara ${ }^{1,2}$ \\ Email : Apriliyadinda21@gmail.com¹,Annionst@gmail.com²
}

\begin{abstract}
Abstrak
Dalam menjalankan suatu pekerjaan akan lebih baik jika dikerjakan secara bersama hal ini dimaksud agar pekerjaan tersebut selesai tepat waktu dan lebih efektif. Sumber daya manusia menjadi salah faktor penting dalam keberhasilan suatu perusahaan untuk mencapai target yang diharapkan. Karyawan pada Bank Sumut Syariah KCPsy Kisaran ssaat ini masih minim sehingga banyak pekerjaan ynag di kerjakan secara rangkap atau bisa disebuat dengan rangkap jabatan guna untuk menyelesaikan pekerjaan agar mencapai target yang di harapkan. Ini sangat berpengaruj terhadap kinerja yang dilkaukan pada semua karyawan dan sangat membutuh beberapa karyawan ( rekrutmen ) agar mempermudah segala kegiatan yang ada kantor bank Sumut Syariah KCPsy Kisaran.
\end{abstract}

Kata Kunci: Sumber Daya Manusia, Rekrutmen dan Kinerja Karyawan

\section{Abstract}

In $n$ carrying out a job, it will be better if it is done together, this is so that the work is completed on time and more effectively. Human resources are an important factor in the success of a company to achieve the expected targets. Employees at Bank Sumut Syariah KCPsy The current range is still minimal so a lot of work is done in duplicate or can be made with multiple positions in order to complete the work in order to achieve the expected target. This is very influential on the performance that is carried out on all employees and really needs some employees (recruitment) to facilitate all activities at the North Sumatra Sharia bank office KCPsy Kisaran.

Keywords: Human Resources, Recrutment and Employee Performance 


\section{INTRODUCTION}

Di era saat ini yang penuh dengan tantangan seperti ketersediaan Sumber Daya Manusia (SDM) yang unggul, andal dan terampil bagi perusahaan atau organisasi yang memiliki tujuan dan bentuk berbeda-beda, merupakan syarat mutlak supaya keberadaannya bisa merespon era yang penuh dengan persaingan ketat pada masa ini (Budi W. Soetjipto,2008)

Menurut Wirawan Suatu organisasi akan berhasil dan efektif karena di dalamnya memiliki kinerja yang baik dan ditopang oleh sumber daya manusia yang berkualitas. Sumber daya manusia merupakan dasar dan kunci dari semua sumber organisasi. Sumber daya manusia yang berkualitas mempunyai pengetahuan, keterampilan, kompetensi, kewirausahaan dan kesehatan fisik dan jiwa yang prima, bertalenta, mempunyai etos kerja dan motivasi kerja tinggi yang dapat membuat organisasi berbeda antara sukses dan kegagalan.Untuk menunjang pencapaian keberhasilan itu suatu perusahaan perlu adanya manajemen sumber daya manusia, dimana dengan adanya fungsi ini dapat meningkatkan sumber daya manusia yang dimiliki oleh perusahaan. Definisi Sumber Daya Manusia itu sendiri adalah manusia yang bekerja dilingkungan suatu organisasi (personil, tenaga kerja, pegawai atau karyawan), serta berpotensi manusiawi sebagai penggerak organisasi untuk mewujudkan eksistensinya, potensi yang merupakan asset yang berfungsi sebagai modal (non material) didalam organisasi bisnis yang dapat diwujudkan menjadi potensi nyata secara fisik dan non fisik dalam eksistensi organisasi untuk mencapai keberhasilan suatu perusahaan. Manajemen sumber daya manusia bermaksud memperbaiki kontribusi produktif orang-orang terhadap organisasi dengan cara yang bertanggung jaawab secara strategis, etis dan sosial.

Hubungan sumber daya manusia dengan manajemen merupakan proses usaha pencapaian tujuan melalui kerja sama dengan oranglain, hal ini menunjukkan pemanfaatan sumber daya manusia untuk mencapai tujuan organisasi (Abdurrahmat Fathoni) Semakin penting peran manajemen dalam mengelolah sumber daya manusia maka perlu adanya pembinaan serta evaluasi perkembangan pegawai yang dimiliki dengan menilai hasil pekerjaan yang mereka lakukan. 
Melihat hal ini kurangnya sumber daya manusia akan menjadi kendala bagi pertumbuhan suatu perusahaan, karena akan membuat suatu pekerjaan menjadi menumpuk dan berdampak pada kinerja serta eksistensi suatu perusahaan, kurangnya sumber daya manusia ini juga akan berdampak adanya rangkap jabatan para pegawainya ini dimaksud seorang pegawai akan memiliki pekerjaan serta tanggung jawab yang lebih banyak.

Tujuan dari penelitian ini adalah untuk melihat kurangnya sumber daya manusia yang dimiliki suatu perusahaan akankah berdampak pada efektifitas serta eksistensi suatu perusahaan tersebut dalam mencapai kinerja perusahan yang baik. Pada PT. Bank Sumut KCP Syariah Kisaran terlihat adanya kekurangan sumber daya manusia yang dimiliki oleh Bank, penelitian ini dianggap menarik karena dengan adanya penelitian ini dapat dijadikan masukan kepada PT. Bank Sumut KCP Syariah Kisaran untuk menambah jumlah sumber daya manusia agar pekerjaan para pegawai dapat diselesaikan dengan lebih efektif serta dapat mencapai kinerja dan hasil dalam pencapaian laba yang lebih baik lagi

\section{LANDASAN TEORI}

\section{A. Manajemen dan Sumber Daya Manusia}

Buchari Zainun mengemukakan bahwa manajemen SDM merupakan hakikat dari manajemen itu sendiri. Sumber daya manusia (human resources) adalah sumber daya yang berperan penting dalam manajemen. Manusia tetap mememiliki peranan yang sangat penting dalam mencapai kesuksesan suatu organisasi meskipun saat ini teknologi telah berkembang sangat pesat.

Pengelolaan SDM menjadi bagian yang sangat penting dari tugas manajemen organisasi. Seberapa baik SDM dikelola akan menentukan kesuksesan organisasi di masa akan datang. Sebaliknya, jika SDM tidak dikelola dengan baik, efektivitas tidak akan tercapai. Sumber Daya Manusia (SDM) merupakan salah satu unsur yang paling vital bagi organisasi. Hal ini terjadi karena pertama, SDM sangat mempengaruhi efisiensi dan efektivitas organisasi, SDM 
merancang dan memproduksi barang dan jasa, mengawasi kualitas, memasarkan produk, mengalokasikan sumber daya financial, serta menentukan seluruh tujuan dan strategi organisasi. kedua, SDM merupakan pengeluaran utama organisasi dalam menjalankan bisnis.Karena pentingnya manajemen SDM ini, bila diabaikan, organisasi tidak akan berhasil mencapai tujuan dan sasaran (French,1986) Manajemen SDM meliputi pemograman, pengarahan, pengorganisasian, pengawasan kegiatan yang dilakukan, pengadaan, pemberian kompensasi, pengembangan, pemeliharaan sumber daya manusia agar tujuan dari individu, organisasi atau perusahaan dan masyarakat dapat terealisasi. Manajeman sumber daya manusia befungsi sebagai pemikat, penyeleksi, pengguna, pemelihara dan pengembangan organisasi (Soekidjo Notoatmodjo, 1998 ).

Sumber daya manusia merupakan suatu modal dasar yang paling utama dalam setiap organisasi. Tanpa adanya sumber daya manusia, dapat dipastikan roda organisasi tidak akan bergerak. Sumber daya manusia dapat didefinisikan sebagai individu yang merancang dan memproduksi keluaran dalam rangka pencapaian strategi dan tujuan yang telah ditetapkan oleh organisasi. Tanpa individu yang memiliki keahlian atau kompeten mustahil bagi organisasi atau perusahaan untuk mencapai tujuan.

Perencanaan sumber daya manusia juga memiliki manfaat diantaranya adalah :

\section{Membuat Kinerja Perusahaan Efektif dan Efisien}

Perencanaan SDM yang tepat sasaran akan membuat perusahaan lebih efektif dan efisien. Artinya, perusahaan berjalan baik dengan personel yang produktif dan jumlah karyawan yang sesuai dengan kebutuhan. Karyawan yang produktif adalah karyawan yang mampu bekerja sesuai dengan SOP dengan jam kerja yang sudah ditentukan. Mereka adalah orang-orang yang mengerjakan dan menghasilkan lebih banyak daripada karyawan rata-rata. Dengan produktivitas 
yang tinggi, tidak dibutuhkan jam kerja ekstra (lembur) ataupun karyawan yang banyak untuk mencapai tujuan perusahaan.

\section{Menimbulkan Sikap Positif Karyawan}

Perencanaan SDM yang baik akan menimbulkan sikap positif dalam diri karyawan. Jenjang karir yang jelas, pelatihan teknis dan soft skills yang rutin berkesinambungan, serta sistem kompensasi dan insentif yang menarik membuat karyawan nyaman dalam bekerja. Mereka merasa memiliki kemampuan dan mendapat ruang kesempatan yang cukup untuk terus maju bertumbuh di dalam dan bersama perusahaan. Karyawan tahu mereka diperhatikan dan dihargai dengan tulus, daripada hanya sekedar menjadi "sapi perah" perusahaan. Survei di beberapa negara menunjukkan bahwa gaji atau penghasilan bukanlah faktor utama seseorang bertahan dalam pekerjaannya.

\section{Meningkatkan Kompetensi Karyawan}

SDM yang kompeten akan didapatkan dengan perencanaan yang terarah. Hanya karyawan dengan kinerja bagus yang akan terus mendorong kemajuan perusahaan. Karyawan yang tidak mau berkembang akan otomatis terdesak oleh sistem. Mereka tidak bisa lagi mengandalkan senioritas dalam lingkup pekerjaan. Sistem SDM yang baik mampu meningkatkan koordinasi antar karyawan dan juga menciptakan atmosfir kerja yang nyaman dan kondusif. Rasa kekeluargaan bisa dipupuk dan bertumbuh baik, sehingga hanya ada sedikit perbedaan di pikiran karyawan antara rumah dan tempat bekerja.

\section{Memperkuat Posisi Perusahaan di Tengah Persaingan}

Banyak perusahaan berlomba-lomba untuk menjadi yang paling unggul. Namun, tidak semua perusahaan mampu saling mengungguli satu sama lain. Hal ini dikarenakan kompetensi tiap perusahaan yang berbeda. Maka dari itulah setiap perusahaan selalu berupaya untuk meningkatkan kompetensi perusahaan melalui perencanaan SDM. Ketika perusahaan mempunyai kompetensi yang cukup, perusahaan akan lebih kokoh dan kuat walau arus persaingan bisnis antar perusahaan semakin ketat. 
Terdapat beberapa pendekatan dalam manajemen sumber daya manusia,antara lain:

1. Pendekatan strategis. Manajeman SDM harus memberikan andil ayas keberhasilan strategis perusahaan. Bila aktivitas manajer dan bagian SDM mencapai sasaran strategisnya, maka sumber daya tidak digunakan secara efektif.

2. Pendekatan SDM. Manajemen SDM merupakan manajemen manusia, sehingga pentingnya martabat manusia tidak boleh diabaikan.

3. Pendekatan manajemen. Manajemen SDM Merupakan tanggung jawab setiap manajer. Departemen SDM ada dalam rangka melayani manajer dan karyawan melalui keahliannya.

4. Pendekatan sistem. Pendekatan SDM berlangsung didalam sistem yang lebih besar, yakni perusahaan. Oleh karenanya, upaya SDM harus mengevaluasi andil karyawan yang diberikan terhadap produktivitas perusahaan.

5. Pendekatan proaktif. Manajemen SDM bisa meningkatkan andilnya atas karyawan dan organisasi dengan mengantisipasi berbagai masalah sebelum masalah tersebut muncul.

\section{B. Rekrutment}

Menurut Wilson (2012), penarikan tenaga kerja (recruitment) merupakan proses pencarian calon karyawan yang memenuhi syarat dalam jumlah dan jenisyang dibutuhkan. Penarikan tenaga kerja berkaitan dengan pemenuhan kebutuhan tenaga kerja sesuai dengan jumlah dan kualitasnya, baik dalam jangka pendek, menengah dan panjang. Menurut Rivai (2004), Rekrutmen merupakan proses menentukan dan menarik pelamar yang mampu untuk bekerja dalam suatu perusahaan, proses ini dimulai ketika para pelamar dicari dan berakhir ketika lamaran lamaran mereka diserahkan atau dikumpulkan, hasilnya adalah merupakan sekumpulan pelamar calon karyawan yang diseleksi dan dipilih. 


\section{Kinerja}

Kinerja dapat diartikan sebagai hasil kerja yang dapat dicapai oleh seseorang atau sekelompok orang dalam organisasi, sesuai wewenang dan tanggung jawab masing-masing, dalam rangka mencapai tujuan organisasi bersangkutan secara legal, tidak melanggar hukum dan sesuai dengan moral maupun etika.Kinerja, merupakan tolak ukur karyawan dalam melaksanakan seluruh tugas yang ditargetkan pada karyawan, sehingga upaya untuk mengadakan penilaian terhadap kinerja di suatu organisasi merupakan hal penting. (Prawirosentono, 1999).

Oleh karena itu kinerja juga membutuhkan manajemen agar hasil yang diperoleh atau kinerja karyawan atau karyawan dapat mencapai hasil yang diinginkan oleh perusahaan. Kinerja diukur dengan instrumen yang dikembangkan dalam studi yang tergabung dalam ukuran kinerja secara umum, kemudian di Terjemahkan ke dalam penilaian perilaku secara mendasar. Menurut Gomez dalam Rahadi, untuk melakukan penelitian terhadap kinerja ada delapan dimensi dalam melakukan pengukuran kinerja pegawai, yaitu: (1) Quality of Work (kualitas kerja), (2) Quantity of Work (kuantitas kerja), (3) Job Knowledge (pengetahuan kerja), (4) Creativeness (kreatifitas), (5) Cooperative (kerjasama), (6) Initiative (inisiatif), (7) Dependability (ketergantungan), (8) Personal Qualities (kualitas personal).

\section{Permasalahan Penelitian}

Kurangnya Sumber Daya Manusia dalam suatu perusahaan dapat berdampak pada efektifitas serta eksistensi suatu perusahaan yang akan menimbulkan adanya beberapa rangkap jabatan yang terjadi dimana ini dimaksud adanya satu orang yang merangkap jabatan dan mengerjakan semua pekerjaannya sendiri serta mempertangung jawabkannya, adanya rangkap jabatan ini dapat membuat kinerja seorang pegawai dapat terhambat dan menjadi tidak efektif. Ini akan sangat berpengaruh pada setiap kualitas pekerjaan yang dikerjakan oleh pegawai baik dari sisi waktu pengerjaan serta teknis pekerjaan yang mereka lakukan.

\section{Tujuan Penelitian}


Penelitian ini bertujuan untuk melihat kurangnya sumber daya manusia pada PT. Bank Sumut KCP Syariah Kisaran akankah berdampak pada efektifitas serta eksistensi dalam bekerja suatu perusahaan tersebut demi pencapaian kinerja perusahan yang baik. dengan adanya penelitian ini dapat dijadikan masukan kepada PT. Bank Sumut KCP Syariah Kisaran untuk menambah jumlah sumber daya manusia agar pekerjaan para pegawai dapat diselesaikan dengan lebih efektif serta dapat mencapai kinerja dalam pencapaian laba yang maksimal

\section{METODE PENELITIAN / METHODS}

Pada penelitian ini merupakan penelitian lapangan (field research) dengan menggunakan pendekatan kualitatif, dimana pendekatan ini membahas tentang fakta dan objek penelitian dengan mencari informasi sesuai dengan persepsi penulis dan menginterpretasikan makna yang tersurat dan tersirat dari penjelasan yang diperoleh dari informan, hasil observasi lapangan, wawancara, dan catatan pribadi. Data yang digunakan dalam penelitian adalah data primer dengan mewawancarai bagian Analis Pembiayaan PT. Bank Sumut KCP Syariah Kisaran J1. HOS Cokroaminoto Kota Kisaran Barat, Kabupaten Asahan dan juga data sekunder yang diperoleh dari studi pustaka, baik dari jurnal, buku maupun website.

Teknik pengumpulan data yang dilakukan pada penelitian ini yaitu melalui observasi, wawancara dan juga dokumentasi. Sedangkan teknik analisis data menggunakan tiga tahap yaitu dimulai dengan tahap reduksi data, tahap penyajian data, dan tahap penarikan kesimpulan.(Sugiyono, 2010). Data yang telah dikumpulkan, selanjutnya dianalisis atas data tersebut. Yang kemudian dibuat kesimpulan secara rapi dan teratur menggunakan metode deskriptif kualitatif. Dan terakhir dikelompokkan, disusun serta di uraikan dengan gambaran kata-kata ataupun kalimat sehingga dapat ditarik kesimpulan

\section{DISCUSSION}

Buah pikiran serta ide dalam mewujudkan pendirian Unit Usaha Syariah nyatanya telah merekah cukup lama di lingkungan para stakeholders PT.Bank Sumut, terutama bagian direksi dan komisaris, yakni mulai dari terbentuknya UU No. 10 Tahun 1998 yang menghadirkan peluang untuk bank konvensional dalam pendirian Unit Usaha Syariah. Unit Usaha Syariah yang 
dibentuk harus dilandaskan pada norma dan gaya hidup masyarakat Sumatera Utara yang religius terutama bagi umat muslim yang semakin paham betapa pentingnya menerapkan ajaran Islam dalam seluruh dimensi kehidupan baik di bidang ekonomi sekalipun. Kegigihan dalam pendirian Unit Usaha Syariah semakin meningkat sejalan dengan adanya fatwa MUI yang menyebutkan haramnya bunga. Sudah jelas bahwa dengan adanya fatwa ini memantapkan dambaan umat muslim untuk memperoleh layanan jasa perbankan berlandaskan unsur-unsur syariah Islam. Peninjauan yang diterapkan delapan kota di Sumatera Utara memperlihatkan hasil yang menyatakan bahwa ketertarikan masyarakat terhadap jasa Bank Syariah cukup tinggi ialah mencakup 70\% dalam hal minat atau rasa tertarik dan lebih dari 50\% untuk keinginan menerima jasa layanan perbankan syariah.

Berdasarkan hal tersebut maka PT. Bank Sumut bertekad untuk meningkatkan perkembangan jasa layanan bank syariah. Pada tanggal 4 November 2004 berdirilah Unit Usaha Syariah yang dibuka PT. Bank Sumut. Unit Usaha Syariah didirikan dengan dua kantor cabang syariah yaitu Kantor Cabang Syariah Padang Sidempuan dan Kantor Cabang Syariah Medan. Bank Sumut Syariah juga telah berdiri di Kisaran pada tanggal 14 Desember 2009.

Unit Usaha Syariah memiliki visi dan misi yang harus menyokong visi dan misi PT. Bank Sumut secara universal maka dari itu ditetapkanlah visi dan misi diantaranya:

1. Unit Usaha Syariah memiliki visi yaitu "mengembangkan nilai mutu PT. Bank Sumut dengan menghadirkan jasa layanan yang berkualitas sesuai dengan prinsip-prinsip syariah yang nantinya mendukung keikutsertaan masyarakat secara universal dalam pengembangan daerah untuk merealisasikan masyarakat yang tenteram dan makmur”.

2. Dan memiliki misi yaitu PT. Bank Sumut ialah "Memperkuat kedudukan PT. Bank Sumut melalui tahap pelayanan jasa perbankan syariah yang aman dan nyaman, adil serta saling melengkapi dalam mengambil peran besar berdasarkan visi dan misinya. Jika dilaksanakan dengan baik maka akan sangat menguntungkan".

Layanan perbankan syariah yang dikembangkan ini diharapkan dapat membantu PT. Bank Sumut untuk tetap maju dalam memperluas usahanya dan dapat mencapai target dalam 
meningkatkan keuntungan dan profitabilitas PT. Bank Sumut serta mempertahankan tingkat kesehatannya. PT. Bank Sumut Kantor Cabang Pembantu Syariah Kisaran merupakan sebuah badan usaha yang bergerak dalam bidang keuangan dan perbankan yang berbentuk badan hukum yang berupa Perseroan Terbatas yang beroperasi menurut prinsip-prinsip syariah. PT. Bank Sumut KCP Syariah Kisaran ini dalam kegiatan sehari harinya yaitu menghimpun dan menyalurkan dana dalam bentuk pembiayaan dengan prinsip-prinsip syariah. Sumber Daya Manusia atau di singkat SDM merupakan salah satu indikator yang menjadi permasalahan dalam penelitian ini, saat ini SDM yang ada di Bank Sumut Kantor Cabang Pembantu Syariah Kisaran masih minim dan tidak sebanding dengan pekerjaan yang ada. Salah satu permasalahan yang menjadi kendala berkembangnya lembaga keuangan syariah ialah SDM secara Kuantitas dan kualitas masih rendah. Kurangnya Sumber Daya Manusia dalam suatu perusahaan dapat menimbulkan adanya beberapa rangkap jabatan yang terjadi dimana ini dimaksud adanya satu orang yang merangkap jabatan dan mengerjakan semua pekerjaannya sendiri serta mempertangung jawabkannya, adanya rangkap jabatan ini dapat membuat kinerja seorang pegawai dapat terhambat dan menjadi tidak efektif. Oleh karenanya, kinerja juga membutuhkan manajemen agar hasil yang diperoleh atau kinerja dari para pegawai dapat mencapai hasil yang ditujukan oleh perusahaan. Hasil kerja yang diharapkan berkualitas dan kuantitas yang dapat dicapai oleh seorang karyawan dalam melaksanakan tugas agar sesuai dengan tanggungjawab yang diberikan kepadanya.

SDM mempengaruhi keberhasilan setiap perusahaan atau organisasi. Tujuan manajemen SDM adalah meningkatkan kontribusi produktif orang-orang yang ada dalam perusahaan melalui sejumlah cara yang bertanggung jawab secara strategis, etis, dan sosial. Indikator dari perencanaan SDM salah satunya melakukan perencanaan rekrutmen, rekrutmen yaitu upaya perusahaan untuk mendapatkan dan menarik tenaga kerja yang diperlukan sesuai dengan kualifikasi yang telah ditetapkan dalam perencanaan tenaga kerja. Rekrutmen merupakan proses menentukan dan menarik pelamar yang mampu untuk bekerja dalam suatu perusahaan. Proses ini dimulai dari mencari pelamar dan berakhir dengan mengumpulkan lamaran-lamaran mereka. Bank Sumut KCPSy Kisaran saat ini memiliki jumlah 4 karyawan tetap untuk pegawai front liner terdiri dari 2 orang pegawai sama halnya di bagian back office yang memilki 2 orang 
pegawai. Dalam kegiatan nya setiap bank memiliki target dalam setiap bulan maupun setiap tahunnya, untuk mencapai itu semua pastilah banyak faktor yang mempengaruhi diantaranya ialah SDM yang ada di bank itu. Hal ini terjadi pada Bank Sumut KCPSy Kisaran yang masih minim akan SDM dimana ditambah nasabah yang semakin bertambah di saat jam operasional kantor yang membuat ketidak efektivan dalam kinerja yang dilakukan karyawa . Kadang banyak karyawan yang lembur untuk mencapai target yang di harapkan tetapi disisi lainya ini membuat pekerjaan tidak efesien ditambah lagi adanya karyawan yang rangkap jabatan akibat kurangnya SDM yang ada di Bank Sumut KCPSy Kisaran ini. Solusi yang penulis berikan ban Sumut KCPSy Kisaran sebaiknya melakukan rekrutmen untuk mencari SDM guna menunjang efektivitas dan efisien dalam bekerja agar semua target akan terpenuhi sesua yng di harapkan bank. Diantaranya dampak positif dari rangkap jabatan adalah minimnya biaya gaji tenaga kerja yang diperkerjakan akan membuat laba yang diperoleh oleh perusahaan menjadi lebih besar dikarenakan biaya pengeluaran gaji yang minim dan itu menguntungkan bagi perusahaan, kemudian pemimpin dapat lebih mudah mengontrol dan mengawasi pekerjaan para pegawainya. Disamping dampak positif tersebut adanya dampak negative yang terjadi diantaranya adalah pekerjaan akan menjadi terhambat jika pegawai ada yang berhalangan untuk hadir dalam bekerja, pekerjaan akan terhambat dikarenakan pegawai memiliki tugas dan tanggung jawab yang lebih banyak sehingga dianggap kurang efektif.

\section{CONCLUSION}

Berdasarkan hasil penelitian dan pembahasan yang telah dilakukan oleh penulis pada PT. Bank Sumut KCP Syariah Kisaran serta pembahasan yang diuraikan oleh penulis, maka dapat ditarik kesimpulan yaitu PT.Bank Sumut KCP Syariah Kisaran masih kekurangan Sumber Daya Manusia. Hal itu memiliki dampak negative dan positif pada perusahaan, dimana perusahaan dan pegawai akan mampu efektif dalam menjalankan pekerjaannya jika dapat memanajemen tugas dan tanggung jawab yang diberikan dengan baik.

Indikator dari perencanaan SDM salah satunya melakukan perencanaan rekrutmen, rekrutmen yaitu upaya perusahaan untuk mendapatkan dan menarik tenaga kerja yang diperlukan sesuai dengan kualifikasi yang telah ditetapkan dalam perencanaan tenaga kerja. Rekrutmen 
merupakan proses menentukan dan menarik pelamar yang mampu untuk bekerja dalam suatu perusahaan. Tujuan manajemen SDM adalah meningkatkan kontribusi produktif orang-orang yang ada dalam perusahaan melalui sejumlah cara yang bertanggung jawab secara strategis, etis, dan sosial.

\section{SARAN}

Penulis menyadari bahwa didalam penelitian ini masih banyak memiliki kesalahan dan kekurangan. Untuk itu, penulis mengharapkan kritik dan saran yang membangun agar dapat menjadi perbaikan dikemudian hari. Penulis juga memiliki saran serta masukan untuk pihak Bank Sumut KCP Syariah Kisaran agar dapat menambah jumlah pegawai khususnya pada back office dimana diharapkan dapat meningkatkan keefektivan para pegawai dalam bekerja serta menigkatkan kinerja perusahaan menjadi lebih baik lagi. 


\section{DAFTAR PUSTAKA}

Soetjipto Budi W.2008. Kisah Sukses Para Kampium SDM. Jakarta: Salemba empat.

Wirawan. 2009. Evaluasi Kinerja Sumber Daya Manusia, Teori, Aplikasi dan Penelitian. Jakarta: Salemba Empat.

Fathoni, Abdurrahmat. 2006. Organisasi dan Manajemen Sumber Daya Manusia. Jakarta: PT. Rineka Cipta.

Suryadi Prawirosentono, Kebijakan Kinerja Karyawan, Yogyakarta: BPFE, 1999.

Dedi Rianto Rahadi, Manajemen Kinerja Sumber Daya Manusia (Malang: Tunggal Mandiri Publishing, 2010.

Rivai Veithzal. 2004. Manajemen Sumber Daya Manusia Untuk Perusahaan, PT Raja Grafindo Persada Jakarta

Wibowo. 2013. Manajemen Sumber Daya Manusia (Edisi Revisi). Surabaya : CV. R.A.De.Rozarie.

Buchari, Zainun. Manajemen Sumber Daya Manusia Indonesia. Jakarta: PT Gunung Agung, 2002

Rukmini, Sri Rukmiyanti. 2014. Pengaruh Kompetensi Sumber Daya Manusia Terhadap Efektivitas Kerja Karyawan Pada PT. Kawasan Wisata Pantai Cermin Theme Park dan Resort Hotel. Jurnal: Ekonomikawan 14 (1), 28886.

Prasista, Asa Bucek (ed). 2017. Analisis Efektivitas dan Dampak Rangkap Jabatan Dalam Peningkatan Kinerja Organisasi Pada PT. Harta Ajeg Lestari, Di Kelurahan Banyuning, Kecamatan Buleleng. Jurnal: Akuntansi Vol : 8 No : 2 
Volume 03 Nomor 012021 : page 36-48 p-ISSN: 2686-262X e-ISSN : 2685-9300 